\title{
DEVELOPMENT OF NEW ACTIVATED CARBON AND TESTS OF CONSTRUCTION MATERIALS IN THE DIAGNOSIS AND TREATMENT FACILITIES FOR CHEMICAL SENSITIVITY
}

Development of new diagnosis and treatment facilities for chemical sensitivity Part 1 化学物質過敏症治療施設における化学物質除去用活性炭の開発および建築部材の決定 化学物質過敏症治療施設の開発 その 1

\author{
Hideto MIKAMI ${ }^{*}$, Huaipeng TANG $^{* *}$ and Shintaro YOKOYAMA*** \\ 三上秀人*，湯 懐 鵬**，横山真太郎***
}

\begin{abstract}
Chemical Sensitivity (CS) is a disorder in which people report negative symptoms in response to chemical exposure. To examine and treat CS patients, special facilities are needed in which chemical contaminants are minimized. The purpose of this study is to establish methods of reducing contaminant concentrations in new diagnosis and treatment facilities for CS. We developed a special activated carbon (SAC) for the chemical filters, and tested their performance. It was confirmed that SAC was superior to commercial activated carbon for reducing chemicals and particle emissions. We also determined suitable construction materials for the facilities by chemical emission tests, and developed a new bond without polymers for the facilities.
\end{abstract}

Keywords: 化学物質過敏症，診断・治療施設，空気清浄，活性炭，アウトガス試験

chemical sensitivity, diagnosis and treatment facilities, air cleaning, activated carbon, emission test

\section{Introduction}

Recently, Chemical Sensitivity (CS) has come to be regarded as a serious disorder. CS refers to a condition in which people report negative symptoms in response to chemical exposure at levels commonly considered to be safe. Symptoms of CS are diverse and uncharacteristic, such as fatigue, headache, dizziness and stomach pain, or allergic symptoms such as eczema, contact dermatitis, and atopic dermatitis ${ }^{1)}$. CS is triggered by exposure to high levels of chemicals or chronic exposure to chemicals such as pesticides, wallpaper, and construction materials typically used in houses.

To diagnose and treat CS patients, special facilities are needed in which chemical contaminants are minimized ${ }^{2}$. The target values of contaminants in the facilities are $10 \mu \mathrm{g} / \mathrm{m}^{3}$ of TVOC (Total Volatile Organic Compounds) and $30 \mu \mathrm{g} / \mathrm{m}^{3}$ of NMHC (Non Methane Hydro Carbon).

Conventional methods of reducing contaminants in indoor air are ventilation, source control and air cleaning ${ }^{3)}$.

Ventilation is a commonly used method for indoor air cleaning. However, outdoor air is not perfectly fresh for CS patients because the TVOC concentration in outdoor air may reach $1000 \mu \mathrm{g} / \mathrm{m}^{3}$ and some contaminants may cause symptoms among CS patients. Therefore, outdoor air needs to be cleaned and the flow rate for ventilation must be minimized.
Sources must be strictly controlled in the facilities because emissions are directly linked to indoor pollution and require larger air cleaning devices. All emission sources in the facilities need to be investigated and minimized.

Air cleaning in the facilities is necessary in order to remove contaminants contained in outdoor and emitted in the facilities. Activated carbon filters are used to remove low levels of contaminants. Activated carbon must have a long life, as well as low emissions of particles and chemicals.

The purpose of this study is to establish methods of reducing contaminant concentrations when building new diagnosis and treatment facilities for CS. We describe the development of activated carbon filters and determination of the construction materials by measuring emissions from them.

\section{Methods of new activated carbon tests and construction material tests} 2.1 New activated carbon tests

Activated carbon filters are used to remove organic contaminants in the air of places such as semiconductor clean rooms, car cabins and general buildings.

Filters require high removal performance, long life, and a low pressure drop. Moreover, the casings or gaskets of filters must have low levels of chemical emission in the facilities.

* Manager, Research \& Development Center, Shinryo Corporation, Dr. Eng.

** Manager, Research \& Development Center, Shinryo Corporation, Dr. Eng.

*** Prof., Environmental Ergonomics, Graduate School of Engineering Science, Hokkaido University, Dr. Med.

新菱冷熱工業株中央研究所 専任課長 ·丁博

新菱冷熱工業(株)中央研究所 専任課長·工博

北海道大学大学院工学研究科空間性能システム専攻

教授・医博 
There are many types of activated carbon filters, and granular carbon filters are used for handling high volumes because of their long life. However, granular carbon filters emit particles, and so HEPA filters are required. HEPA filters emit chemicals mainly from their binder. Nowadays, low-emission filters are commercially available for semiconductor clean rooms, but emissions are not completely eliminated and the filters still have a faint odor. CS patients are very sensitive to odors, and so HEPA filters should not be installed after activated carbon filters.

We have developed a new special activated carbon (SAC). SAC is a coconut based activated carbon, the surface of which is covered with sodium silicate. SAC is made by dipping activated carbon into a sodium silicate solution in an airtight container, decompressing at $10 \mathrm{kPa}$ by vacuum pump for 2 hours, and drying it at $55^{\circ} \mathrm{C}$. We evaluated the lifetime and emission rate of particles of SAC and commercial activated carbon.

Breakthrough tests were performed on both SAC and the coconut based commercial activated carbon. Benzene and formaldehyde were selected as challenge gases in these breakthrough tests, because benzene breaks relatively early in a VOC and is the most suitable index of lifetime measurement, while formaldehyde is widely known to cause CS and its removability needs to be confirmed.

A schematic diagram of the experiment is shown in Fig. 1. The target carbon was packed into a column (length: $0.15 \mathrm{~m}$, diameter: $0.1 \mathrm{~m}$, bed volume: $0.0011 \mathrm{~m}^{3}$ ). Inlet air temperature and humidity were controlled at $23^{\circ} \mathrm{C}$ and $50 \%$ R.H., and delivered to the target carbon at $11.1 \mathrm{~m}^{3} / \mathrm{h}$. Benzene and formaldehyde were generated by injection from a syringe pump and delivered into the inlet air. The inlet concentration of benzene was controlled at $50 \mathrm{ppm}$, and that of formaldehyde at $4 \mathrm{ppm}$. Benzene was sampled by a gas-tight syringe and trapped with TENAX TA adsorbent, and analyzed by GC/MS (HP-6890/HP-5973, Agilent Technologies, Inc.). The concentration of benzene was calculated by subtraction of the blank value of benzene generated from TENAX TA. Formaldehyde was sampled by a DNPH cartridge and analyzed by HPLC (HP-1050, Agilent Technologies Inc.).

In addition, particle emission tests were performed on both SAC and the coconut based commercial activated carbon. A schematic diagram of the experiment is shown in Fig. 2.

$98 \mathrm{~cm}^{3}$ of the target carbon was filled in a test chamber of $50 \mathrm{~mm}$ inside diameter. Air was provided by an air-pump and passed through a HEPA filter to the target carbon. The flow rate was $4.2 \mathrm{~m}^{3} / \mathrm{h}$, and velocity through the target carbon was $0.6 \mathrm{~m} / \mathrm{s}$. Particles of both inlet and outlet of the target carbon were measured by a particle counter (KC-01D, RION Co., Ltd.).

\subsection{Construction material test}

We tried to determine suitable construction materials for diagnosis and treatment facilities for CS for the chemical emission tests. To reduce the emission of chemicals in the facilities, we measured the emission rate of chemicals from construction materials (the floor and the wall materials; the ducts and the gaskets), and decided their specifications.

Chemical emission tests were conducted based on the ASTM standard guide $^{4)}$ (Fig. 3). The volume of the test chamber was $0.06 \mathrm{~m}^{3}$, the flow rate

of $\mathrm{N}_{2}$ was $0.18 \mathrm{~m}^{3} / \mathrm{h}$, and the air exchange rate of the test chamber was 3.0 $\mathrm{h}^{-1}$. The $\mathrm{N}_{2}$ temperature and relative humidity conditions inside the chamber were controlled at $23^{\circ} \mathrm{C}$ and $50 \%$, respectively. VOC was sampled with TENAX TA tubes and analyzed with GC/MS ${ }^{5)}$. Emission tests of formaldehyde were also carried out for low emission samples. Formaldehyde was sampled with a DNPH cartridge and analyzed by HPLC (HP-1050, Agilent Technologies Inc.).

Table 1 shows the preparation of samples. Each sample was tested after being stored in a clean bench with an activated carbon filter for 14 days. The specimen area of each sample was $0.18 \mathrm{~m}^{3}$.

Emission rates were calculated from the measured data for flow rate $(Q)$, concentrations $\left(C_{o}\right.$ and $\left.C_{i}\right)$ and surface area of each material $(A)$ as shown in

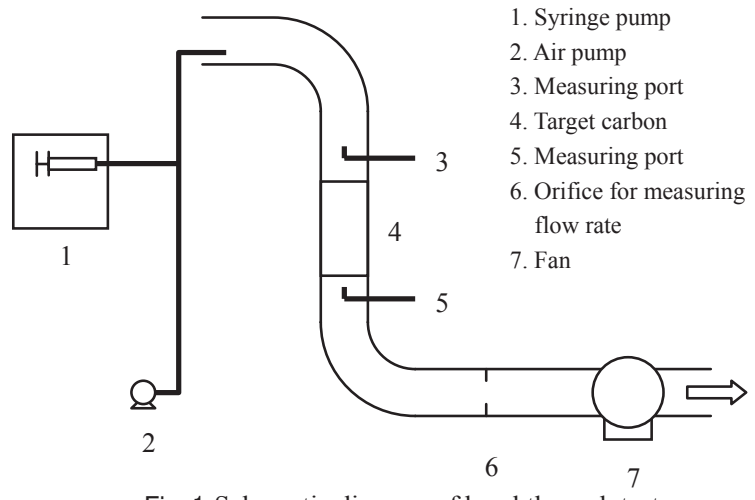

Fig. 1 Schematic diagram of breakthrough tests

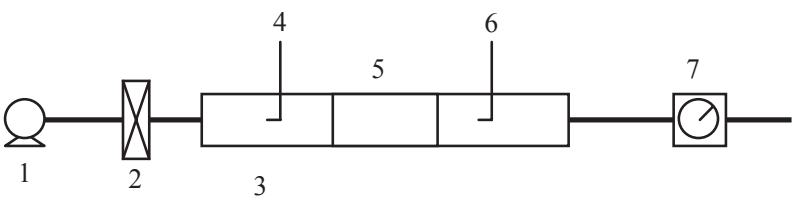

1. Air pump 2. HEPA filter 3. Test chamber 4. Measuring port $\begin{array}{lll}5 \text {. Target carbon } \quad 6 \text {. Measuring port } \quad 7 \text {. Flow meter } & \end{array}$

Fig. 2 Schematic diagram of particle emission tests

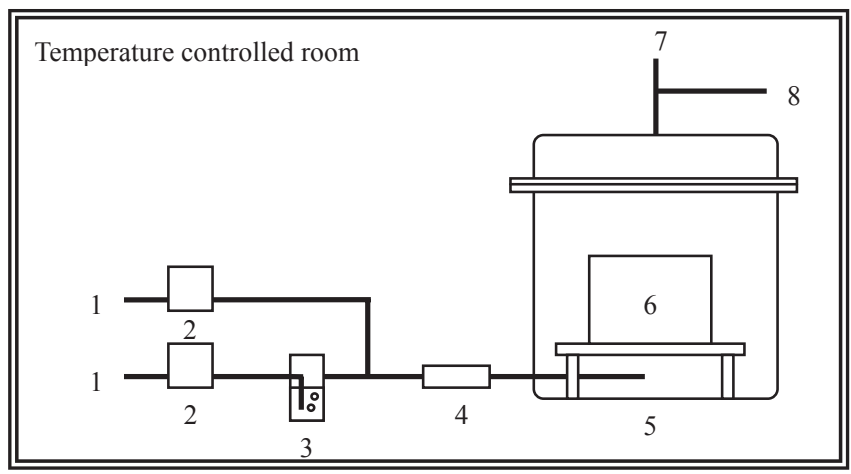

1. Purified $\mathrm{N}_{2}$ 2. Mass flow controller 3. Humidifier (bubbling to deionized water) 4. Charcoal filter 5. Test chamber 6. Sample 7. Measuring port 8 . Exhaust

Fig. 3 Schematic diagram of chemical emission tests 
the following equation $(1)^{6}$.

$$
M=\left(C_{o}-C_{i}\right) \frac{Q}{A}
$$

where

$$
\begin{aligned}
& M: \text { Emission rate }\left[\mu \mathrm{g} / \mathrm{h} / \mathrm{m}^{2}\right] \\
& C_{o}: \text { Outlet concentration }\left[\mu \mathrm{g} / \mathrm{m}^{3}\right] \\
& C_{i}: \text { Inlet concentration }\left[\mu \mathrm{g} / \mathrm{m}^{3}\right] \\
& A: \text { Surface area of material }\left[\mathrm{m}^{2}\right]
\end{aligned}
$$

\section{Results of and discussion on new activated carbon and construction}

\section{material tests}

3.1 New activated carbon tests

Figure 4 shows the raw breakthrough curves of each carbon for $50 \mathrm{ppm}$ benzene. There were no differences in removal efficiency during the first 24 hours, and 90\% efficiency time was 21 hours. Figure 5 shows the relationship between adsorption amount per unit volume of carbon and removal efficiency. Supposing that the removal efficiency of carbon is determined by only adsorption amount per volume, then the following equation (2) can be used:

$1-\rho=0.000048 \exp (0.2313 q)$

where,

$\rho:$ removal efficiency, [-]

$q$ :adsorption amount per volume $[\mathrm{g} / \mathrm{L}]$

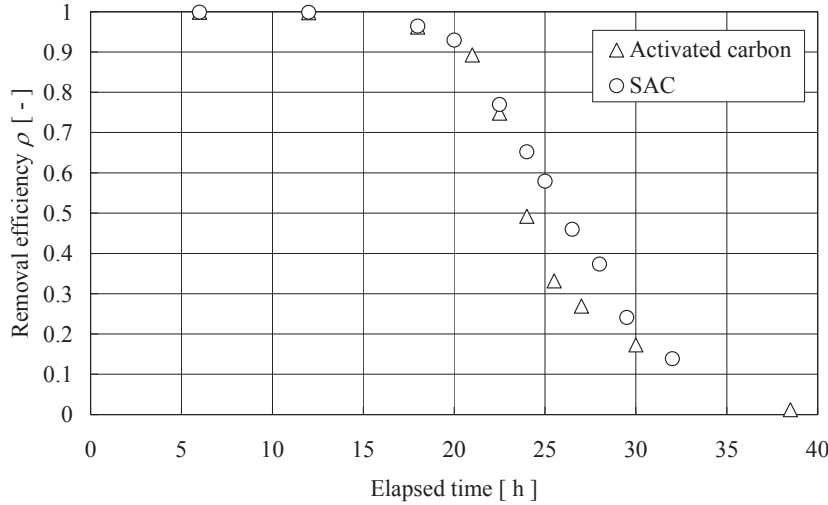

Fig. 4 Breakthrough curves for benzene

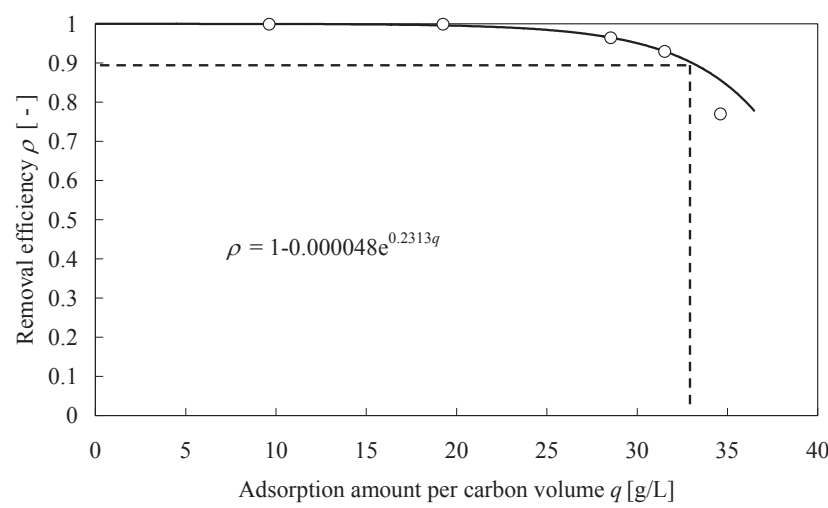

Fig. 5 Relationship between adsorption amount per unit volume of carbon and removal efficiency (benzene)
Table 1 Preparation of samples

\begin{tabular}{|l|l|}
\hline & Method of preparation \\
\hline Paint & Painting both side of degreased SUS plate \\
\hline Gasket & $\begin{array}{l}\text { Sticking gaskets ( } 9 \mathrm{~mm} \text { to } 15 \mathrm{~mm} \text { in width) on } \\
\text { degreased SUS plate with no clearance }\end{array}$ \\
\hline Sealant & Coating degreased SUS plate at $5 \mathrm{~mm}$ thick. \\
\hline Metal plate & None \\
\hline Stone & None \\
\hline Bond & Coating degreased SUS plate at $5 \mathrm{~mm}$ thick. \\
\hline
\end{tabular}

In case of benzene concentration of $0.5 \mathrm{mg} / \mathrm{m}^{3}$, which was the same level as the equivalent outdoor concentration of TVOC in the Tokyo Metropolitan District, lifetime of SAC together with the coconut based activated carbon was estimated at 6,000 hours by using the equation (2).

The raw breakthrough curves of two carbon types for $4 \mathrm{ppm}$ formaldehyde are shown in Fig. 6. Although the concentration level of formaldehyde is one - thirteenth of the benzene test, the initial removal efficiency was under $90 \%$. The level of removal efficiency during 5 hours afterward was around $50 \%$, which was lower compared with that of $100 \%$ in case of benzene. It is demonstrated that the removal efficiency of carbon for formaldehyde was lower than that for benzene throughout our total tests.

Figure 7 shows the relationship between adsorption amount per unit volume of carbon and removal efficiency. For formaldehyde,

$\rho=2.3663 \exp q^{-0.2861}$

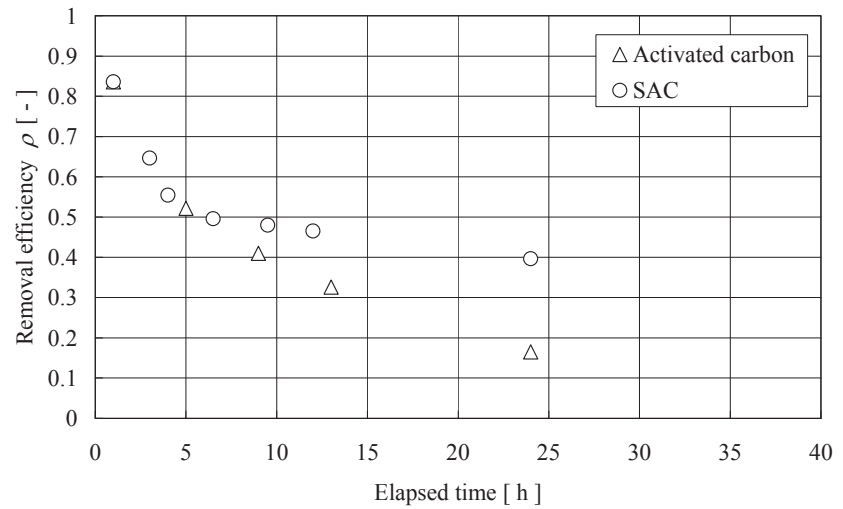

Fig. 6 Breakthrough curves for formaldehyde

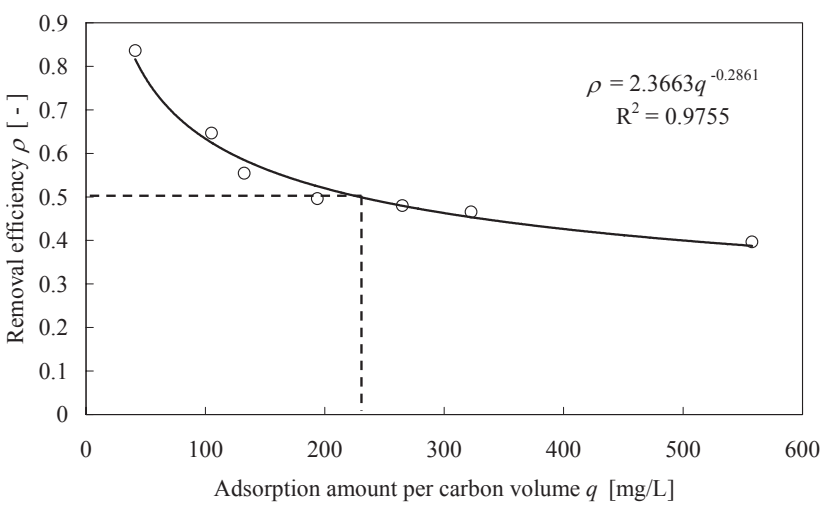

Fig. 7 Relationship between adsorption amount per unit volume of carbon and removal efficiency (formaldehyde) 
The difference of removal efficiency emerging after five hours, i.e., after less than $50 \%$ removal efficiency, suggests that the use of a suitable impregnant such as sodium silicate can improve the removal efficiency for formaldehyde.

Figure 8 shows particle emissions from each target carbon. The amount of particles from SAC was about one-sixth that of commercial activated carbon. It was confirmed that $\mathrm{SAC}$ is superior to commercial activated carbon on the market concerning prevention of particle emissions together with benzene and formaldehyde.

\subsection{Construction Material Test}

Table 2 summarizes the measurements of chemical emission tests. Emissions from SUS 304 plate, galvanized steel plate, enameled steel plate and granite were not detected. Requirements for construction materials in the facilities are not only low emission but also low stress to CS patients. SUS 304 plate and galvanized steel plate had no emissions, but are unfavorable as wall or flooring materials in terms of stress. Enameled steel plate, on the other hand, can have various colors and so was considered suitable for wall paneling. Similarly, granite stone was chosen as the flooring material. To

Table 2 Results of the chemical emission tests

\begin{tabular}{|c|c|c|c|c|c|}
\hline Name & $\begin{array}{c}\text { Emission } \\
\text { rate of }\end{array}$ & $\begin{array}{c}\text { Emission } \\
\text { rate of } \\
\text { TVOC }\end{array}$ & \multicolumn{3}{|c|}{ Detected VOCs (in order of emission rate) } \\
\hline $\begin{array}{l}\text { Oven-dried solvent-based paint } 1 \\
\text { (acrylic melamine resin) }\end{array}$ & - & 10.5 & Butanoic acid hexyl ester & $\begin{array}{l}\text { 2-(2-Butoxyethoxy)-ethanol } \\
\text { acetate }\end{array}$ & $\begin{array}{l}\text { Propanoic acid, 2-methyl-2,2- } \\
\text { dimethyl ester }\end{array}$ \\
\hline $\begin{array}{l}\text { Oven-dried solvent-based paint } 2 \\
\text { (acrylic melamine resin) }\end{array}$ & - & 5.3 & Aliphatic aldehyde & 2-Methyl propanol & Aliphatic aldehyde \\
\hline $\begin{array}{l}\text { Oven-dried solvent-based paint } 4 \\
\text { (melamine resin) }\end{array}$ & - & 34.4 & Aliphatic aldehyde & Heptenal & 2-Decenal \\
\hline $\begin{array}{l}\text { Air-dried solvent-based paint } 1 \\
\text { (polyurethane modified acrylic resin) }\end{array}$ & - & 119 & unknown & Butanoic acid, butyl ester & 2-(2-Butoxyethoxy)ethanol \\
\hline $\begin{array}{l}\text { Air-dried solvent-based paint } 2 \\
\text { (acrylic resin) }\end{array}$ & - & 366 & unknown & Butanoic acid, butyl ester & Butyl glycol acetate \\
\hline $\begin{array}{l}\text { Air-dried water-based paint } 1 \\
\text { (acrylic resin) }\end{array}$ & - & 552 & Carboxylic acid ester & Butanoic acid, butyl ester & 2-(2-Butoxyethoxy)ethanol \\
\hline $\begin{array}{l}\text { Air-dried water-based paint } 2 \\
\text { (acrylic resin) }\end{array}$ & - & 14.0 & Carboxylic acid ester & Butanoic acid, butyl ester & 2-(2-Butoxyethoxy)ethanol \\
\hline Gasket for ducts 1 (chloroprene) & - & 156 & $\begin{array}{l}\text { 2,6-Bis(1,1-dimethylethyl)- } \\
\text { 4-methylphenol }\end{array}$ & Aliphatic hydrocarbon & \\
\hline Gasket for ducts 2 (glass fiber) & - & 43.5 & $\begin{array}{l}\text { 2,6-Bis(1,1-dimethylethyl)- } \\
\text { 4-methylphenol }\end{array}$ & n-Tetradecane & 2-Ethyl-1-hexanol \\
\hline $\begin{array}{l}\text { Gasket for ducts } 3 \\
\text { (ethylene-vinyl acetate) }\end{array}$ & - & 33.6 & $\begin{array}{l}\text { 2,6-Bis(1,1-dimethylethyl)- } \\
\text { 4-methylphenol }\end{array}$ & Nonanal & n-Tetradecane \\
\hline $\begin{array}{l}\text { Gasket for ducts } 4 \\
\text { (ethylene propylene diene monomer) }\end{array}$ & - & 61.9 & $\begin{array}{l}\text { 2,6-Bis(1,1-dimethylethyl)- } \\
\text { 4-methylphenol }\end{array}$ & Aliphatic hydrocarbon & \\
\hline $\begin{array}{l}\text { Sealant for ducts } 1 \\
\text { (acrylonitrile-butadiene rubber) }\end{array}$ & - & 348 & Toluene & n-Decane & n-Undecane \\
\hline $\begin{array}{l}\text { Sealant for ducts } 2 \\
\text { (acrylonitrile-butadiene rubber) }\end{array}$ & - & 294 & Toluene & $\begin{array}{l}\text { 2,6-Bis(1,1-dimethylethyl)- } \\
\text { 4-methylphenol }\end{array}$ & Unknown \\
\hline SUS-304 plate & $<0.2$ & $<0.2$ & & & \\
\hline Porcelain enamel steel plate & $<0.2$ & $<0.2$ & & & \\
\hline Granite & $<0.2$ & $<0.2$ & & & \\
\hline $\begin{array}{l}\text { Bond for tiles } 1 \\
\text { (Cement and epoxy resin) }\end{array}$ & - & 31.8 & Xylene & Ethylbenzene & Toluene \\
\hline $\begin{array}{l}\text { Bond for tiles } 2 \\
\text { (Cement and epoxy resin) }\end{array}$ & - & 18.3 & Toluene & Xylene & Ethylbenzene \\
\hline $\begin{array}{l}\begin{array}{l}\text { Bond for tiles } 3 \\
\text { (Cement and epoxy resin) }\end{array} \\
\end{array}$ & - & 9.4 & Xylene & n-Tridecane & Ethylbenzene \\
\hline New bond for tiles without polymers & $<0.2$ & $<0.2$ & & & \\
\hline Teflon gasket & $<0.2$ & 27.0 & $\begin{array}{l}\text { 2,5-Di-tert-butyl-1,4- } \\
\text { benzoquinone }\end{array}$ & Aliphatic hydrocarbon & Aliphatic hydrocarbon \\
\hline Silicone sealant 1 (for general use) & - & 7420 & 2-Butanone, oxime & Octamethylcyclotetrasiloxane & Decamethylcyclopentasiloxane \\
\hline Silicone sealant 2 (for clean room) & - & 2710 & 2,4-Pentanedione & 4-Methyl-2-pentanone & Decamethylcyclopentasiloxane \\
\hline
\end{tabular}


overcome the problem of emissions from the bonding of granite, we developed a new bond which was a mixture of kaolin, rock wool and sodium silicate without polymers or solvents; there were no emissions from the new bond. Gaskets made of Teflon had the lowest emissions among the present duct materials. Ducts, air handling units or diffusers were greased when they were shaped such as cutting, bending or drilling. Washing by an alkaline solution is needed for degreasing them, and so stainless steel should be used as the main material due to its resistance to degreasing agents.

\section{Conclusions}

We developed a special activated carbon and tested its performance by breakthrough tests and particle emission tests. Breakthrough tests were carried out by using benzene and formaldehyde. The results showed that SAC equaled or was superior to commercial activated carbon. Furthermore, particle emissions of SAC were one-sixth that of commercial activated carbon. It was confirmed that SAC was superior to commercial activated carbon.

We also carried out chemical emission tests to determine suitable construction materials for the facilities. As a result, it was decided that the wall paneling should be enameled steel panel and the flooring material should be granite stone considering emissions and stress to patients. It was also decided that ducts and air handling units should be stainless steel, and gaskets should be made of Teflon. We also developed a new bond without polymers or solvents.

\section{Acknowledgements}

We thank both Prof. Satoshi Ishikawa and Mikio Miyata for their suggestions, and also the present director Masao Hirano and the former director Kimio Senda of Shinryo R\&D Center for their support and encouragement.

\section{References}

1) Cullen, M. R.: The worker with multiple chemical sensitivities: An overview. Occupational Medicine: State of Art Reviews, 2, pp. 655-661, 1987

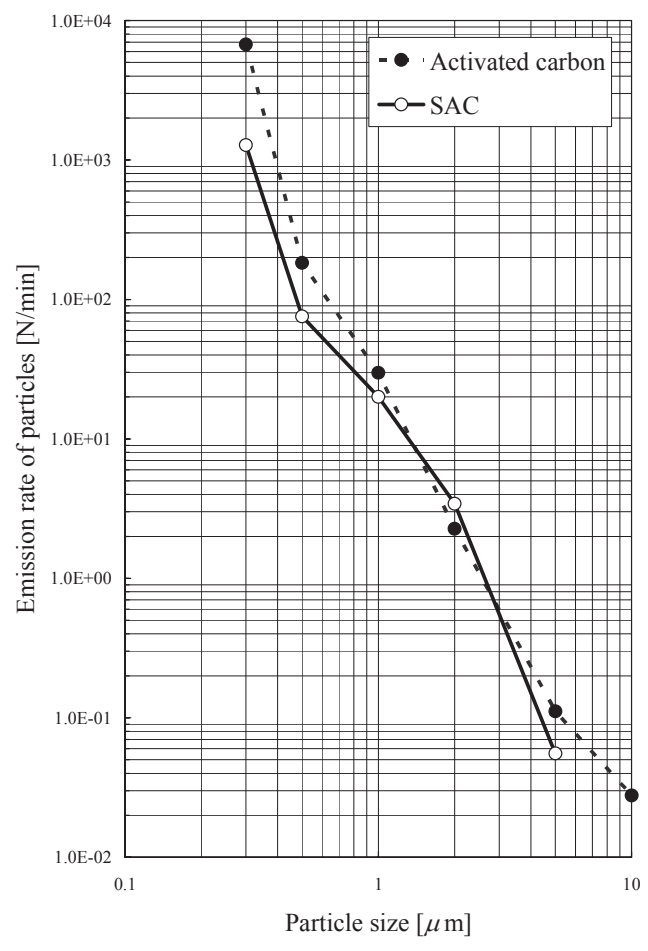

Fig. 8 Results of the particle emission tests

2) Ishikawa, S., Miyata, M.: Chemical sensitivity and its clinical characteristics in Japan, Asian Med. J. 43 (1), pp. 7-151, 2000

3) ASHRAE: Control of Gaseous Indoor Air Contaminants, HVAC Applications, 45.1 45. 14,2003

4) ASTM: Small-Scale Environmental Chamber Determinations of Organic Emissions from Indoor Materials / Products, ASTM Standard D5116-90, 1990

5) Afshari, A., Lundgren, B., Ekberg, L. E. Comparison of three small chamber test methods for the measurement of VOC emission rates from paint, Indoor air, 13, pp. 156-165, 2003

6) Haghighat, F: Measurement of diffusion coefficients of VOCs for building materials: review and development of a calculation procedure. Indoor Air, 12, pp. 81-91, 2002

\section{和文要約}

化学物質過敏症（C S）は化学物質の急性曝露あるいは低濃度の慢 性曝露によって過敏性を取得し，その後に極低濃度の化学物質曝露に よりアレルギー様の症状を示すようになる健康障害である。症状は 様々で, 疲労感, 頭痛, 倦忠感, 腹痛やぜんそく, 皮膚炎など多岐に わたる。C S を診断・治療するには，空気中の污染物質を除去した専 門の治療施設が必要とされており，その清浄度目標值はVOC で $10 \mu \mathrm{g} / \mathrm{m}^{3}$ ，非メタン炭化水素（NMHC）で $30 \mu \mathrm{g} / \mathrm{m}^{3}$ である。

治療施設内の清浄度目標值は外気濃度よりも低いため, 導入外気は 污染物質を除去する活性炭フィルターが必要であり, 室内で発生した 污染物質を除去するために，循環系統にも活性炭フィルターが必要で ある。一方, 建築部材から発生する污染物質は室内を污染すると共に,
循環系統の活性炭フィルターのコストを高めるため，極力污染物質 の発生の少ない建築部材を選定する必要がある。本研究の目的は, C $\mathrm{S}$ の診断・治療施設の建設に先立ち, 污染物質の濃度を低減する技術 を確立することであり，本報はその第 1 報として，治療施設用に開発 した特殊活性炭の性能試験と, 治療施設の建築部材の選定についての 報告である。

粒状炭を充填した充填式の活性炭フィルターは長寿命であること から, 大風量を処理する場合に使用されるが, 発塵量が大きいため, 二次側にHE P A フィルターなどの塵埃除去フィルターが必要であ る。H E P A フィルターはアウトガスの問題と僅かな特有の臭気の問 題があり，治療施設では活性炭フィルターの 2 次側に設置すべきでは 
ない。そこで，筆者らは発塵を抑制するために，活性炭表面を珪酸ナ トリウムで被覆した特殊活性炭（ＳＡＣ）を試作した。S A C は，椰 子款活性炭を珪酸ナトリウム溶液に含浸して減圧し, その後乾燥して 作成した。このS A C と市販の梆子殼活性炭について, 寿命と発塵の 点について性能評価を行った。

寿命試験は Fig. 1 に示寸実験装置において行った。試験用ガスには ベンゼンを使用し，ホルムアルデヒドについても同様の試験を行った。 濃度を一定に調整した空気を供試活性炭に流通させ，経過時間と除去 率の関係を調べた。発塺試験は Fig. 2 に示す実験装置において行った。 SUS 容器に供試活性炭を入れ, HEPA フィルターでパーティクルを除 去した空気を流通させ，発塵量を測定した。

ベンゼンの寿命試験結果では，S A C と市販の活性炭の寿命は同等 であった。除去能力は活性炭単位体積あたりの吸着量で決定されると 仮定して, 東京都心部の外気を導入した場合の寿命を試算した。東京 都心部の TVOC 濃度をベンゼン濃度に換算して $0.5 \mathrm{mg} / \mathrm{m}^{3}$ とすると, 6000 時間と試算された。ホルムアルデヒドの寿命試験結果では, 両者 とも寿命が非常に短いことが確認されたが，除去率 $50 \%$ 以下に低下し た後の除去率は, S A C の方が優る結果を得た。発塵試験の結果では, S A C の発塵量は椰子殼活性炭の $1 / 6$ 以下であり, 珪酸ナトリウムに
よる表面被覆は発塵の抑制に有効であることを確認した。

次に，建築部材の決定を目的として，Fig. 3 に示寸小形チャンバー 法によりアウトガス試験を行った。試験方法は ASTM D5116-90 に則 った。試験の結果, SUS304, ガルバリウム鋼板, ホーロー鋼板および 御影石からはアウトガスは検出されなかった。アウトガス量および視 覚的なストレスの観点から，天井および壁にはホーロー鋼板，床材に は御影石を採用することとした。カオリン，ロックウールおよび珪酸 ナトリウムを混合して試作した新しい目地材からは，アウトガスは検 出されなかった。ガスケットとしては，テフロン製ガスケットを採用 することとした。ダクトや空調機，制気口などは SUS304 を採用する こととした。

以上の結果より, 今回試作した S A C の寿命は市販の活性炭と同等 以上であり, 発塵量は $1 / 6$ 以下に改善されたことから, 化学物質過敏 症の診断・治療施設において污染物質除去用活性炭として使用できる ことを確認した。また，アウトガス試験により最適な治療施設の建築 部材を決定したことにより，基本仕様を確立した。

（2007年 7 月 9 日原稿受理，2007年12月26日採用決定） 